Academic Platform Journal of Engineering and Science

\title{
Sb Katkılı CuO Filmlerinin Yapısal ve Optik Özellikleri
}

\author{
*1Şilan Baturay \\ ${ }^{* 1}$ Dicle Üniversitesi, Fen Fakültesi, Fizik Bölümü, Diyarbakır/Türkiye, \\ silan@dicle.edu.tr \\ Research Paper \\ Arrival Date: 16.08 .2019 \\ Accepted Date: 18.12.2019
}

$\ddot{O} z$

(111) tercihli yönelimli Sb katkılı $\mathrm{CuO}$ ince film, çeşitli ağırlık oranlarında (ağırlıkça \% 0, 1, 2 ve $3 \mathrm{Sb}$ ), soda kireç cam alttaşı (SLG) üzerine dönel kaplama tekniği kullanılarak büyütüldü. Farklı Sb katkısının CuO filmlerin yapısal, morfolojik ve optik özellikleri üzerindeki etkisi, X-ışını difraksiyon (XRD) ünitesi, taramalı elektron mikroskobu (SEM) ve UV-vis spektrofotometresi kullanılarak kapsamlı bir şekilde incelenmiştir. Filmlerin X 1şını kırınım spektroskopi çalışmaları, ince filmlerin tercihli yönelim boyunca polikristal doğaya sahip olduklarını göstermektedir. Tüm CuO ince film morfolojisi yüzeyde kusur olmaksızın homojen doğaya sahip olduğunu göstermektedir. Elde edilen $\mathrm{CuO}$ filmlerin geçirgenliği, Sb içeriğindeki artışla değişmiştir. Ultraviyole görünür bölge spektrofotometre ölçümleri, elde edilen filmlerin enerji bant aralığında 1.70 'den 2.37 eV'ye kadar radikal bir şekilde artış olduğunu göstermektedir. Sb katkılı CuO ince film optik özelliklerinin önemli ölçüde değiştiği söylenebilir.

Anahtar Kelimeler: İnce film, Geçirgenlik, Enerji bant aralığı, XRD

\section{Structural and Optical Properties of Sb Doped CuO Films}

\author{
*Şilan Baturay \\ ${ }^{* 1}$ Department of Physics, Faculty of Science, Dicle University, Diyarbakir/Turkey, silan@ dicle.edu.tr
}

\begin{abstract}
Preferentially (111) oriented Sb-doped $\mathrm{CuO}$ thin film with various weight fractions $(0,1,2$ and 3 wt $\%$ of $\mathrm{Sb})$ have been grown on soda-lime glass substrate (SLG) by spin coating technique. The effect of Sb doping in different amounts on the structural, morphological and optical properties of $\mathrm{CuO}$ films was comprehensively investigated via X-ray diffraction (XRD) unit, scanning electron microscopy (SEM) and UV-vis spectrophotometer. X-ray diffraction spectroscopy studies of the films indicate that thin films are polycrystalline nature along the preferential direction. The morphology of all $\mathrm{CuO}$ thin film is uniform with no cracking in the surface. The transmittance of the $\mathrm{CuO}$ films changed with an increase in Sb content. Ultraviolet-visible spectrophotometer measurements indicate that a radical increase in the energy band gap of the films with an increase in Sb content from 1.70 to $2.37 \mathrm{eV}$. It can be said that the optical properties of the $\mathrm{Sb}$ doped $\mathrm{CuO}$ thin film were significantly changed.
\end{abstract}

Keywords: Thin film, Transmittance, Energy band gap, XRD

\section{INTRODUCTION}

Technological advancements and nanoscience have played an important role both in encouraging the invention of a new phenomenon, industrial revolutions and in the development of economy for the 21 st century $[1,2]$. In recent years, transition metal oxides have attracted the researchers' interest owing to their unique properties for technological point of view. Among all the transition metal oxides such as iron oxide and zinc oxide nanostructures, copper oxide
$(\mathrm{CuO})$ films have attracted a wide interest because of their immense potential applications in various field of science and technology including optics, optoelectronics, biosensor, solar cell technology, gas sensing, catalysis, transducers and capacitors [2-12]. Transition metal oxides have novel electronic, magnetic and optical properties that are different from their conventional bulk counterparts [11].

Copper oxide thin films are important monoclinic p-type transition metal oxide semiconductor, having a narrow band 
gap of $1.21-2.1 \mathrm{eV}$ [13-15]. $\mathrm{CuO}$ has an important advantage in device applications since it has several attractive features such as favorable capacitive, easily produced in different shapes, low cost, non-toxicity and available resources [16].

$\mathrm{CuO}$ thin films also play an important role in catalysis and solar energy conversion applications because of their several advantages such as high activity and selectivity in reactions [17]. A broad variety of physical and chemical techniques have been used for the fabrication of $\mathrm{CuO}$ films, such as molecular beam epitaxy [18], hydrothermal process [19], thermal evaporation [20], thermal decomposition [21], magnetron sputtering [22], pulsed laser deposition [23]. In this study, the spin coating method is employed to get highquality films to control crystalline growth and amorphous surfaces.

This technique has been proved to be a very efficient method in producing thin films such as relatively homogenous deposition in air condition, easy control of film thickness at different concentrations and fine composition [24, 25]. Besides, a number of metal atoms can be used as doping elements of nanostructured films to improve the physical and chemical properties of materials to meet the specific demand and device applications. Generally, doping elements make radical variation in optical, electrical, structural and magnetic properties of $\mathrm{CuO}$ films by changing electronic properties. $\mathrm{Cu}$ has hole doping and electron doping mechanisms owing to its different oxidation states such as $\mathrm{Cu}^{+}, \mathrm{Cu}^{2+}$ and $\mathrm{Cu}^{3+}[26,27]$.

In recent years, a number of studies have been carried out on doping elements of $\mathrm{CuO}$ thin films however it maintains a difficulty to get high quality of thin films with excellent physical and chemical behavior. Among p-type nanostructured metal oxides, $\mathrm{CuO}$ doped with transition elements has attracted considerable attention for its excellent device application in gas sensor applications, catalysts and spintronic devices owing to high activity and selectivity in reactions and Curie temperature [28]. Many authors have shown that the changes in the material's physical and chemical properties are associated with $\mathrm{CuO}$ doping with various dopants [29-33]. Yun et al. have prepared Sb doped p-type $\mathrm{Cu}_{2} \mathrm{O}$ films by electro deposition method [34]. They showed that the addition of $\mathrm{Sb}$ dopants in the $\mathrm{Cu}_{2} \mathrm{O}$ significantly improved the characteristic properties of the film.

In this study, $\mathrm{Sb}$ doped $\mathrm{CuO}$ films were grown by using spin coating technique. Then, all films were annealed at $450^{\circ} \mathrm{C}$ to develop their properties. The optical, structural and morphological properties of $\mathrm{Sb}$ doped $\mathrm{CuO}$ thin films have not been comprehensively investigated and the knowledge in the literature about this study is very limited. Therefore, the concentration effect on $\mathrm{CuO}$ film was comprehensively investigated in this study.

\section{EXPERIMENTAL}

Pure and $\mathrm{Sb}$ doped $\mathrm{CuO}$ thin films with different weight fractions $(0,1,2$ and $3 \mathrm{wt} \%$ of $\mathrm{Sb})$ were grown by spin coating technique using a solution containing $0.1 \mathrm{M}$ copper (II) acetate $\left(\mathrm{Cu}\left(\mathrm{CH}_{3} \mathrm{COO}\right)_{2} \cdot \mathrm{H}_{2} \mathrm{O}\right), 0.01 \mathrm{M}$ antimony (III) chloride fabricated under optimized condition. To obtain a clear and homogenous blue solution, copper (II) acetate and antimony (III) chloride solutions with a high purity of about $98 \%$ were prepared. $0.1 \mathrm{M}$ copper (II) acetate and $0.01 \mathrm{M}$ antimony (III) chloride solution was separately stirred in ethanol for $24 \mathrm{~h}$. Then, an adequate amount of antimony (III) chloride was slowly mixed into the copper (II) acetate solution to obtain various doping concentrations (i.e. $0,1,2$ and $3 \%$ ) and then the solutions were stirred for $8 \mathrm{~h}$ until a clear and homogeneous blue solution was attained. In this study, it has been reported that various $\mathrm{Sb}$ doping concentrations have effects on $\mathrm{CuO}$ thin film.

Prior to deposition process, the used SLG substrates were firstly boiled in the solution of 5:1:1 $\mathrm{H}_{2} \mathrm{O}$ (water), $\mathrm{NH}_{3}$ (ammonia) and $\mathrm{H}_{2} \mathrm{O}_{2}$ (hydrogen peroxide) for $15 \mathrm{~min}$ at 90 ${ }^{\circ} \mathrm{C}$ and then in the solution of $5: 1: 1 \mathrm{H}_{2} \mathrm{O}$ (water), $\mathrm{H}_{2} \mathrm{O}_{2}$ (hydrogen peroxide) and $\mathrm{HCl}$ (hydrogen chloride) for $15 \mathrm{~min}$ at $90^{\circ} \mathrm{C}$ to obtain a clear surface. Then, these SLG substrates were stirred in acetone for $5 \mathrm{~min}$ to obtain a clear surface. Finally, these substrates were cleaned by double distilled water and then dried.

After drying the substrates and preparing the solutions, the thin films were fabricated using spin coating technique at a spin rate of $2000 \mathrm{rpm}$ for $63 \mathrm{~s}$ for 10 layers of deposition and then, each layer of the thin films was preheated at $220^{\circ} \mathrm{C}$ for 12 min on a hot plate. The Sb-doped $\mathrm{CuO}$ thin films were annealed at $450{ }^{\circ} \mathrm{C}$ for $1 \mathrm{~h}$ in a furnace. The effect of $\mathrm{Sb}$ doping in different amounts on the optical, morphological and structural properties of $\mathrm{CuO}$ thin film was studied in this work. The crystalline properties and phase purity of the acquired Sb-doped $\mathrm{CuO}$ thin film were investigated by an XRay Diffractometer (XRD) unit. The surface morphology of all thin films was obtained by scanning electron microscopy (SEM). The optical measurements such as transmittance and energy band gap of all thin films were analyzed using a UVVis spectrophotometer in the $300-1100 \mathrm{~nm}$ wavelength range.

\section{RESULTS AND DISCUSSION}

\subsection{Structural analysis}

For structural and phase purity analysis, pure and Sb doped $\mathrm{CuO}$ films were deposited on soda-lime glass substrate using spin coating technique, XRD spectrum of all the films was investigated by an X-ray diffractometer and the results are shown in Fig.1. The XRD patterns were investigated at a scan rate of $0.02^{\circ}$ and an operating voltage $(\mathrm{V})$ with current (I) of $40 \mathrm{keV}$ and $30 \mathrm{~mA}$, respectively. 


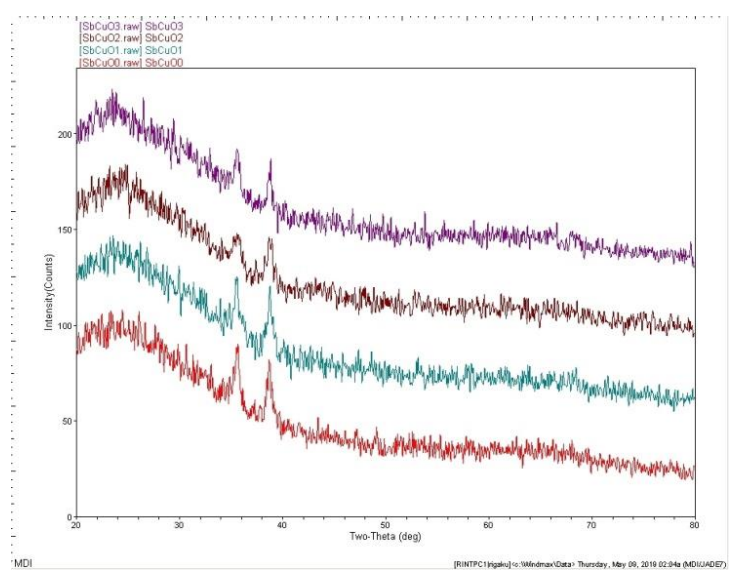

Figure 1: XRD patterns of the films method grown $\mathrm{Cu}_{2} \mathrm{O}$ thin films fabricated at a substrate temperature of $300^{\circ} \mathrm{C}$ [36]. Yoon et al. reported a dominant phase of $\mathrm{CuO}$ prepared using ion beam sputtering method at a different baking temperature ranging from 25 to $400{ }^{\circ} \mathrm{C}$ [37]. Luzeau et al. also reported that a mixture of $\mathrm{Cu}, \mathrm{CuO}$ and $\mathrm{Cu}_{2} \mathrm{O}$ phases fabricated via an oxygen plasma source at a different baking temperature from 450 to $600^{\circ} \mathrm{C}$ [38]. Increasing the $\mathrm{Sb}$ doping caused a decrease in the intensity of all diffraction peaks at first as the intensity of (002) and (111) observed to gradually decrease. However, the peak (111) is still seen even for the highest Sb doping. It is important to note here that the intensities of XRD peaks declined as $\mathrm{Sb}$ was doped in $\mathrm{CuO}$ and increasing Sb doping in $\mathrm{CuO}$ thin films caused degenerate the crystalline quality of films. For the $\mathrm{Sb}(0,1,2$ and $3 \%)$ doped $\mathrm{CuO}$ thin film, crystallite size $(D)$ was calculated by measuring the peak full width at half maximum (FWHM) using the Scherrer's equation [10].

$D=\frac{0.94 \lambda}{\beta \cos \theta}$

Table1: Structural parameters derived from XRD measurements of pure and $\mathrm{Sb}$ doped $\mathrm{CuO}$ thin film films.

\begin{tabular}{|c|c|c|c|c|c|c|c|}
\hline Sample & $\begin{array}{l}2 \text { theta } \\
\text { (Degree) }\end{array}$ & $\begin{array}{l}\text { FWHM } \\
\text { (degree) }\end{array}$ & Grain Size (̊̊) & $\begin{array}{r}\text { d-Spacing } \\
(\AA ̊)\end{array}$ & $\begin{array}{l}\text { Dislocation } \\
\text { Density } \\
(\delta) \times 10^{14} \\
\left(\mathrm{~m}^{-2}\right)\end{array}$ & Strain $\left(10^{-4}\right)$ & Orientation \\
\hline \multirow[t]{3}{*}{ Pure $\mathrm{CuO}$} & 35.56 & 0.546 & 160.2 & 2.5225 & 38.97 & 22.62 & 002 \\
\hline & 35.68 & 0.543 & 160.3 & 2.5143 & 38.92 & 22.61 & -111 \\
\hline & 38.70 & 0.468 & 187.3 & 2.3248 & 28.51 & 19.34 & 111 \\
\hline \multirow{2}{*}{ 1\% Sb:CuO } & 35.62 & 0.543 & 161.9 & 2.5185 & 38.15 & 22.61 & -111 \\
\hline & 38.82 & 0.541 & 163.5 & 2.3180 & 37.41 & 22.16 & 111 \\
\hline \multirow[t]{2}{*}{ 2\% Sb:CuO } & 38.68 & 0.682 & 129.1 & 2.3259 & 60.00 & 28.07 & 111 \\
\hline & 39.00 & 0.610 & 145.0 & 2.3076 & 47.56 & 25.10 & 200 \\
\hline 3\% Sb:CuO & 38.88 & 0.468 & 148.4 & 2.3144 & 45.41 & 19.33 & 111 \\
\hline
\end{tabular}

It can be seen in Fig. 1 that all films have polycrystalline nature, giving the formation of monoclinic structure. The peak positions of the XRD pattern were located at around $2 \theta$ $=35.5,35.6,38.7$ and $39.00^{\circ}$ corresponding to (002), (-111), (111) and (200) planes for $\mathrm{Sb}(0,1,2$ and 3\%) doped $\mathrm{CuO}$ film, respectively. Furthermore, we can see from the XRD data that there are clear changes in the peak positions in the spectra, which may be attributed to the substitution of $\mathrm{Cu}$ atoms by $\mathrm{Sb}$ atoms affecting the monoclinic structure of the parent $\mathrm{CuO}$ thin films. Sekhar indicated that $\mathrm{CuO}$ thin film has (002) and (111) planes when thin films were deposited at 400-500 ${ }^{\circ} \mathrm{C}$ temperature [35]. Maruyama reported that both $\mathrm{Cu}_{2} \mathrm{O}$ and $\mathrm{CuO}$ phases using chemical vapor deposition where $\lambda$ is the wavelength of the $\mathrm{X}$-ray beam (1.5418 $\AA$ ), $\theta$ is the Bragg diffraction angle and $\beta$ is the angular width of the peak at half-width maximum (FWHM) and $D$ is the calculated crystalline size of the $\mathrm{CuO}$ films, as indicated in Table 1.

It can be seen in Table 1 that the crystallite size of Sb doped $\mathrm{CuO}$ films was found to be in the range of 12.9-18.7 $\mathrm{nm}$. This shows that the crystallite size changes with the increase of $\mathrm{Sb}$ doping in $\mathrm{CuO}$ film, which may be owing to high radius $(121.76 \AA)$ of $\mathrm{Sb}$ ions in solution. Balamurugan and Mehta indicated that as the oxygen flow rate increases, the crystallite size of the film decreases [13]. Gülen et al reported that the crystallite size of $0.02 \% \mathrm{Mn}$-doped $\mathrm{CuO}$ film 
decreases while the crystallite size of 0.06 and $0.10 \mathrm{Mn}$ doped $\mathrm{CuO}$ film increases [39].

The dislocation density value $\delta$ (the number of defects in $\mathrm{CuO}$ films) is calculated using the following equation:

$\delta=\frac{1}{D^{2}}$

where $D$ is the crystallite size. Strain $(\varepsilon)$ of the pure and Sbdoped $\mathrm{CuO}$ films is calculated from the following equation:

$\varepsilon=\frac{\beta}{4 \tan \theta}$

Both strain and dislocation density in our work changed with increasing of $\mathrm{Sb}$ concentration in the solution. The changing of the dislocation density shows deterioration of the crystallinity with an increase in Sb doping effect. We can see in Table 1 that the main cause of change in crystallite size for all orientation is associated with a change in strain. These changes indicate the proof of the strain in the pure and Sbdoped $\mathrm{CuO}$ films.

\subsection{Surface morphology studies}

The SEM images of pure and 1, 2, 3\% Sb-doped $\mathrm{CuO}$ thin film with various $\mathrm{Sb}$ concentrations are shown in Fig 2 (a, b, c and d), respectively.
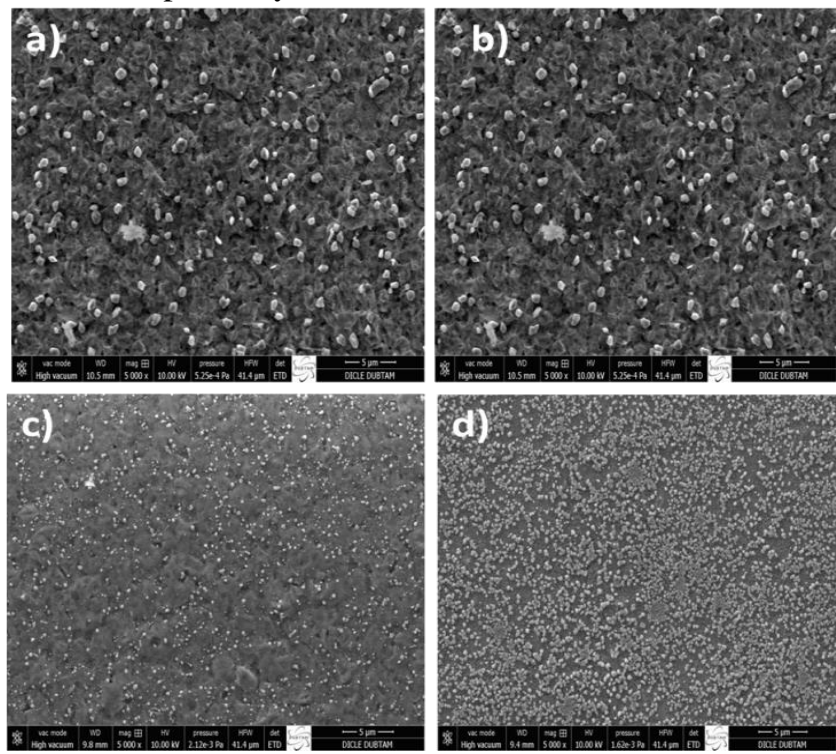

Figure 2: SEM image of a) pure $\mathrm{CuO}$ film, b) $1 \% \mathrm{Sb}$-doped $\mathrm{CuO}$ film, c) $2 \% \mathrm{Sb}$-doped $\mathrm{CuO}$ film, d) $3 \% \mathrm{Sb}$-doped $\mathrm{CuO}$ film

As seen in Fig. 2, the surface topology of the thin films has uniform surfaces without any cracks or pinholes for all $\mathrm{CuO}$ films. The surface topology of the films has comparatively smooth surfaces and grains are spherical. It can be said that all thin film surface is also composed of densely packed nanoparticles and the coverage rate of the nanoparticles comparatively increased with $\mathrm{Sb}$. A similar change in the SEM images was reported in our previous work [40].
Additionally, it can be said that the doping concentration of $\mathrm{Sb}$ affected the appearance of the Sb-doped $\mathrm{CuO}$ film's surface topology.

\subsection{Optical studies}

The optical properties of $\mathrm{CuO}$ films fabricated onto sodalime glass substrates were analyzed to observe the effect of doping on the energy band gap $E_{g}(\lambda)$ and the transmittance $T(\lambda)$ by using a UV-visible spectrophotometer in the wavelength range from 300 to $1100 \mathrm{~nm}$. There was not seen any other peak in the UV-vis area because all thin films have a good quality (clear and homogenous). Fig. 3 indicates the optical transmission spectra of $\mathrm{CuO}$ films for various concentrations.

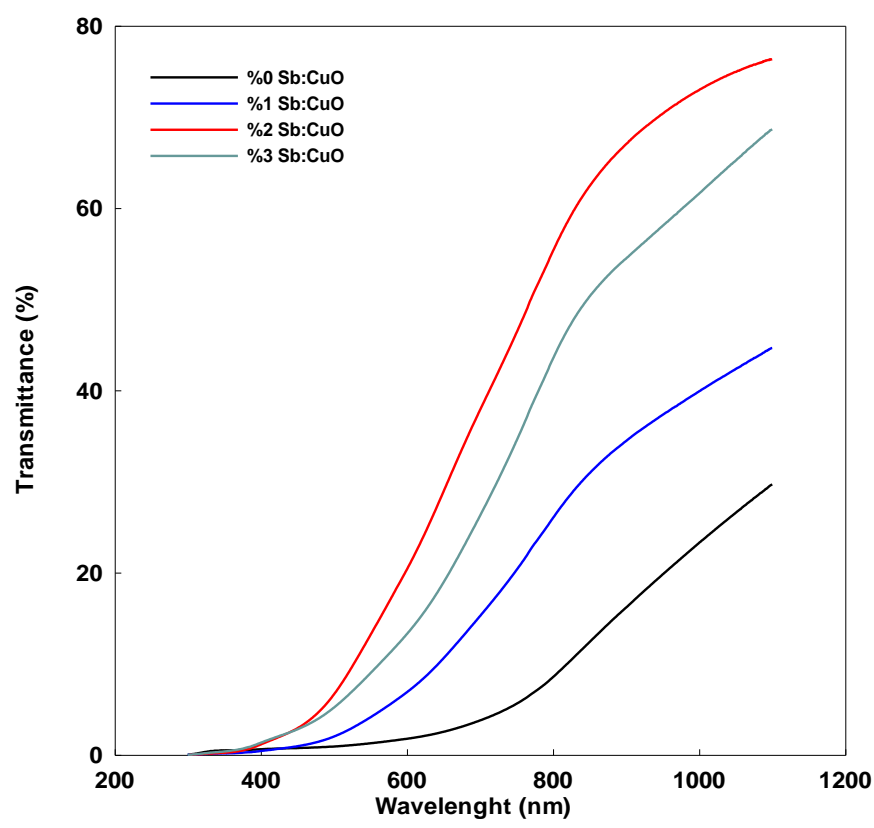

Figure 3: Transmittance of pure and $\mathrm{Sb}$ doped $\mathrm{CuO}$ thin films

Pure $\mathrm{CuO}$ thin film has a minimum transmittance value compared to the other thin films. Gülen et al. indicated that pure $\mathrm{CuO}$ transmits the higher wavelengths at small percentages using SILAR method and they showed that Mndoped $\mathrm{CuO}$ film exhibited transparency around 80\% [39]. Also, Joseph et al. indicated an enhancement in the transmittance for the spray fabricated $10 \%$ Fe-doped $\mathrm{CuO}$ films [41]. As seen in Fig. 3, the transmission of Sb doping in the solution increases with increasing of incorporation concentrations and the highest transmittance value for films was obtained at $2 \%$ as compared to the others. It can be said that the transmittance value of Sb-doped $\mathrm{CuO}$ thin film changed with $\mathrm{Sb}$ doping level owing to the differences in the microstructure. The energy band gap of pure and $\mathrm{Sb}$-doped $\mathrm{CuO}$ thin films in the wavelength range of 300-1100 nm was investigated and illustrated in Fig. 4. For such materials, optical absorption theory shows that the absorption coefficient $(\alpha)$ and incident photon energy $(h v)$ are correlated as follows: 
$\alpha h v=K\left(h v-E_{g}\right)^{n}$

where $K$ is an energy-independent constant related to the material, $h v$ is the photon energy and $E_{g}$ is the energy band gap. A curve of $(\alpha h v)^{2}$ vs. photon energy $(h v)$ for the $0,1,2$, 3\% Sb-doped $\mathrm{CuO}$ thin film as shown in Fig. 4 (a, b, c and d) indicates the effect of different concentration fractions on the energy band gap $\left(E_{g}\right)$.
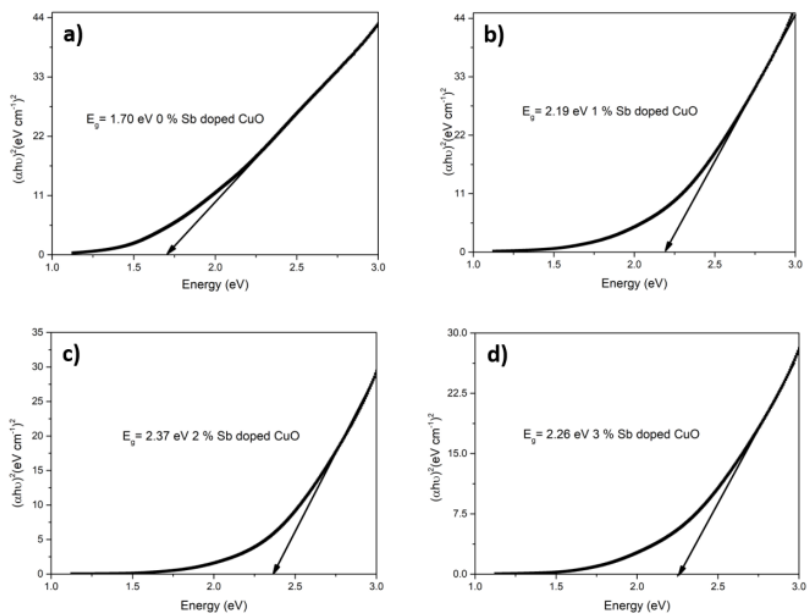

Figure 4: Energy band gap of a) pure $\mathrm{CuO}$ film, b) $1 \% \mathrm{Sb}$ doped $\mathrm{CuO}$ film, c) $2 \% \mathrm{Sb}$-doped $\mathrm{CuO}$ film, d) $3 \% \mathrm{Sb}$-doped $\mathrm{CuO}$ film

The calculated energy band gap of the films found from this curve was $1.70,2.19,2.37$ and $2.26 \mathrm{eV}$ for $0,1,2,3 \% \mathrm{Sb}$ doped $\mathrm{CuO}$ films, respectively. Sb doping has changed the energy band gap owing to the band tailing effect [31], which indicates that $\mathrm{Sb}$ could be used to regulate the optical band gap of $\mathrm{CuO}$ films. Joseph et al. reported that the values of $\mathrm{Eg}$ for the $\mathrm{CuO}$ thin films on doping with $\mathrm{Fe}$ increased [41]. Gülen et al indicated that energy band gap of $\mathrm{Mn}$-doped $\mathrm{CuO}$ films increased from 1.98 to 2.20 related to increasing of $\mathrm{Mn}$ doping fractions [39]. Yildiz et al. showed that energy band gap of In doped $\mathrm{CuO}$ thin films using sol gel dip coating method increases from 1.24 to $1.46 \mathrm{eV}$ with the increasing doping fractions [42].

\section{CONCLUSION}

In summary, we have investigated the structural, morphological and optical properties of pure and $\mathrm{Sb}$ doped $\mathrm{CuO}$ thin film via spin coating technique. The X-ray diffraction pattern study indicates that all thin films have polycrystalline nature and the crystallite size of $\mathrm{CuO}$ films has changed with increasing of Sb doping.

The SEM images of all thin films demonstrate that the morphological properties of all thin films are dependent on $\mathrm{Sb}$ doping fractions. One can easily see that the energy band gap of 1, 2 and $3 \% \mathrm{Sb}$ doped $\mathrm{CuO}$ film increased compared to pure $\mathrm{CuO}$ film. The transmittance value changed depending on $\mathrm{Sb}$ doping fractions and the highest transmittance value was found to be for $2 \% \mathrm{Sb}$-doped $\mathrm{CuO}$ film in the visible range.

\section{REFERENCES}

[1]. M. Sahooli, S. Sabbaghi and R. Saboori, "Synthesis and characterization of mono sized $\mathrm{CuO}$ nanoparticles", Materials Letters, vol. 81, no 15, pp. 169-172, August 2012. [2]. P. Ball and L. Garwin, "Science at the atomic scale. Nature", vol. 355, no. 6363, pp. 761-766, February 1992.

[3]. LC. Chen, "Review of preparation and optoelectronic characteristics of $\mathrm{Cu}_{2} \mathrm{O}$-based solar cells with nanostructure", Materials Science in Semiconductor Processing, vol. 16, no.5, pp. 1172-1185, October 2013.

[4]. X. Zhang, D. Zhang, X. Ni and H. Zheng "Optical and electrochemical properties of nanosized $\mathrm{CuO}$ via thermal decomposition of copper oxalate", Solid-State Electronics, vol. 52, no. 2, p p. 245-248, February 2008.

[5]. Gou, X., G. Wang, J. Yang, J. Parka and D. Wexlera "Chemical synthesis, characterisation and gas sensing performance of copper oxide nanoribbons", Journal of Materials Chemistry, vol. 18, no. 9, pp. 965-969, 2008.

[6]. J. Tamaki, K. Shimanoe, Y. Yamada, Y. Yamamoto, N. Miura and N. Yamazoe "Dilute hydrogen sulfide sensing properties of $\mathrm{CuO}-\mathrm{SnO}_{2}$ thin film prepared by low-pressure evaporation method", Sensors and Actuators B: Chemical, vol. 49, no. 1, pp. 121-125, June 1998.

[7]. SD. Seo, YH. Jin, SH. Lee, HW. Shim and DW. Kim "Low-temperature synthesis of $\mathrm{CuO}$-interlaced nanodiscs for lithium ion battery electrodes", Nanoscale Res. Lett, vol. 6: pp. 2-7, May 2011.

[8]. N. Topnani, S. Kushwaha and T. Athar, "Wet synthesis of copper oxide nanopowder", International Journal of Green Nanotechnology: Materials Science \& Engineering, vol. 1, no. 2, pp. 67-73, November 2010.

[9]. K. Mageshwari, SS. Mali, R Sathyamoorthy and PS: Patil "Template-free synthesis of $\mathrm{MgO}$ nanoparticles for effective photocatalytic applications", Powder technology, vol. 249 , pp. 456-462, November 2013.

[10]. DP. Dubal, GS. Gund, CD. Lokhande and R. Holze " $\mathrm{CuO}$ cauliflowers for supercapacitor application: Novel potentiodynamic deposition”, Materials Research Bulletin, vol. 48, no. 2, pp. 923-928, February 2013.

[11]. NM. Basith, JJ. Vijaya, LJ. Kennedy and M. Bououdina "Structural, morphological, optical, and magnetic properties of $\mathrm{Ni}$-doped $\mathrm{CuO}$ nanostructures prepared by a rapid microwave combustion method", Materials Science in Semiconductor Processing, vol. 17, p p. 110-118, September 2014.

[12]. İY. Erdoğan and Ö. Güllü, "Optical and structural properties of $\mathrm{CuO}$ nanofilm: its diode application", Journal of Alloys and Compounds, vol. 492, no. 1, pp. 378-383, March 2010.

[13]. B. Balamurugan and B. Mehta, "Optical and structural properties of nanocrystalline copper oxide thin films prepared by activated reactive evaporation", Thin Solid Films, vol. 396, no.1, pp. 90-96, September 2001. 
[14]. F. Marabelli, G. Parravicini and F. Salghetti Drioli, "Optical gap of CuO", Physical Review B, vol. 52, no. 3, pp. 1433, July 1995.

[15]. J. Ghijsen, LH. Tjeng, JV. Elp, H. Eskes, J. Westerink, GA. Sawatzky and MT. Czyzyk "Electronic structure of $\mathrm{Cu}_{2} \mathrm{O}$ and $\mathrm{CuO}$ ", Physical Review B, vol. 38, no. 16, pp. 11322, December 1988. 1 of Applied Physics, vol. 101, no. 9, pp. 11322, December 1988.

[16]. A. Oral, E. Menşur, MH. Aslan and E. Başaran "The preparation of copper (II) oxide thin films and the study of their microstructures and optical properties", Materials Chemistry and Physics, vol. 83, no. 1, pp. 140-144, September 2004.

[17]. T. Itoh and K. Maki "Preferentially oriented thin-film growth of $\mathrm{CuO}$ (111) $\mathrm{Cu}_{2} \mathrm{O}$ (001) on $\mathrm{MgO}$ (001) substrate by reactive dc-magnetron sputtering", Vacuum, vol. 81, no. 7, pp. 904-910, February 2007.

[18]. K. Kawaguchi, R Kita, M. Nishiyama and T. Morishita "Molecular beam epitaxy growth of $\mathrm{CuO}$ and $\mathrm{Cu}_{2} \mathrm{O}$ films with controlling the oxygen content by the flux ratio of $\mathrm{Cu} / \mathrm{O}+$ ", Journal of Crystal Growth, vol. 143, no. 3-4, pp. 221-226, October 1994.

[19]. M. Faisal, SB. Khan, MM. Rahman, A. Jamal and A. Umar "Ethanol chemi-sensor: Evaluation of structural, optical and sensing properties of $\mathrm{CuO}$ nanosheets", Materials Letters, vol. 65, no. 9, pp. 1400-1403, May 2011.

[20]. M. Petrantoni, C. Rossi, V. Conedera, D. Bourrier, P. Alphonse and C. Tenailleau "Synthesis process of nanowired $\mathrm{Al} / \mathrm{CuO}$ thermite", Journal of Physics and Chemistry of Solids, vol. 71, no. 2, pp. 80-83, February 2010.

[21]. L. Zhang, R. Liu and H. Yang "Preparation and sonocatalytic activity of monodisperse porous bread-like $\mathrm{CuO}$ via thermal decomposition of copper oxalate precursors", Physica E: Low-dimensional Systems and Nanostructures, vol. 44, no. 7, pp. 1592-1597, April 2012.

[22]. M. Petrantoni, C. Rossi, L. Salvagnac, V. Conedera, A. Esteve, C. Tenailleau, P. Alphonse and J. Chabal "Multilayered $\mathrm{Al} / \mathrm{CuO}$ thermite formation by reactive magnetron sputtering: Nano versus micro", Journal of Applied Physics, vol. 108, no. 8,: pp. 084323, October 2010. [23]. A. Chen, H. Long, X. Li, Y. Li, G. Yang and P. Lu "Controlled growth and characteristics of single-phase $\mathrm{Cu}_{2} \mathrm{O}$ and $\mathrm{CuO}$ films by pulsed laser deposition", Vacuum, vol. 83, no. 6, pp. 927-930, February 2009.

[24]. HY. Bae and GM. Choi, "Electrical and reducing gas sensing properties of $\mathrm{ZnO}$ and $\mathrm{ZnO}-\mathrm{CuO}$ thin films fabricated by spin coating method", Sensors and Actuators B: Chemical, vol. 55, no. 1, pp. 47-54, April 1999.

[25]. T. Tsuchiya, T. Emoto and T. Sei, "Preparation and properties of transparent conductive thin films by the sol-gel process", Journal of Non-Crystalline Solids, vol. 178, pp. 327-332, November 1994.

[26]. SG. Bahoosh, AT. Apostolov, IN. Apostolova and JM. wesselinowa "Theory of phonon properties in doped and undoped CuO nanoparticles", Physics Letters A, vol. 376, no. 33, pp. 2252-2255, July 2012.

[27]. DP. Joseph, C. Venkateswaran, S. Sambasivam and BC. Choi "Effect of Fe alloying on the structural, optical, electrical and magnetic properties of spray-deposited $\mathrm{CuO}$ thin films", Journal of the Korean Physical Society, vol.. 61, no. 3, pp. 449-454, August 2012.

[28]. T. Itoh and K. Maki "Preferentially oriented thin-film growth of $\mathrm{CuO}(111)$ and $\mathrm{Cu}_{\mathrm{e}} \mathrm{O}(001)$ on $\mathrm{MgO}(001)$ substrate by reactive dc-magnetron sputtering", Vacuum, vol. 8, no. 7, pp. 904-910, February 2007.

[29]. A. Rydosz and A. Szkudlarek "Gas-sensing performance of M-doped CuO-based thin films working at different temperatures upon exposure to propane", Sensors, vol. 15, no. 8, pp. 20069-20085, August 2015.

[30]. H. Zhu, F. Zhao, L. Pan, Y. Zhang, C. Fan, and Y. Zhang "Structural and magnetic properties of Mn-doped $\mathrm{CuO}$ thin films", Journal of Applied Physics, vol. 101, pp. 9H111, December 2007.

[31]. P. Chand, A Gaur, A. Kumar and UK. Gaur "Structural and optical study of $\mathrm{Li}$ doped $\mathrm{CuO}$ thin films on $\mathrm{Si}$ (100) substrate deposited by pulsed laser deposition", Applied Surface Science, vol. 307, pp. 280-286, July 2014.

[32]. JS. Shaikh, RC. Pawar, RS. Devan, YR. Ma, PP. Salvi, SS. Kolekar and PS. Patil "Synthesis and characterization of $\mathrm{Ru}$ doped $\mathrm{CuO}$ thin films for supercapacitor based on Bronsted acidic ionic liquid", Electrochimica Acta, vol. 56, no.5. pp. 2127-2134, February 2011.

[33]. J. Oh, H. Ryu and W J. Lee, "Effects of Fe doping on the photoelectrochemical properties of $\mathrm{CuO}$ photoelectrodes", Composites Part B: Engineering, vol. 163, pp. 59-66, April 2019.

[34]. YD. Yun, SK. Baek, JS. Kim, YB. Kim, SH. Jung, Y. Kim and HK. Cho "Optimal synthesis of antimony-doped cuprous oxides for photoelectrochemical applications", Thin Solid Films, vol. 671, pp. 120-126, February 2019.

[35]. SC. Ray "Preparation of copper oxide thin film by the sol-gel-like dip technique and study of their structural and optical properties", Solar energy materials and solar cells, vol 68. pp. 307-312, June 2001.

[36]. T. Maruyama "Copper oxide thin films prepared by chemical vapor deposition from copper dipivaloylmethanate", Solar energy materials and solar cells, vol. 56, pp. 85-92, September 1998.

[37]. KH. Yoon, WJ. Choi and DH. Kang "Photoelectrochemical properties of copper oxide thin films coated on an n-Si substrate", Thin Solid Films, vol. 372, pp. 250-256, September 2000.

[38]. P. Luzeau, XZ. Xu and M. Laguës "Copper oxide thinfilm growth using an oxygen plasma source", Journal of Vacuum Science \& Technology A: Vacuum, Surfaces, and Films, vol. 8, pp. 3938-3940, July 1990.

[39]. Y. Gülen, F.Bayansal, B.Şahin, HA. Çetinkara and HS. Güder "Fabrication and characterization of $\mathrm{Mn}$-doped $\mathrm{CuO}$ thin films by the SILAR method", Ceramics International, vol. 39, pp. 6475-6480, August 2013.

[40]. Ş. Baturay, A. Tombak, D. Kaya, YS. Ocak, M. Tokus, M. Aydemir and T. Kilicoglu "Modification of electrical and optical properties of $\mathrm{CuO}$ thin films by Ni doping", Journal of Sol-Gel science and Technology, vol. 78, no. 2, pp. 422429, May 2016.

[41]. DP. Joseph, C. Venkateswaran, S. Sambasivam and BB. Choi "Effect of Fe alloying on the structural, optical, electrical and magnetic properties of spray-deposited $\mathrm{CuO}$ 
thin films", Journal of the Korean Physical Society, vol. 61, no.3, pp. 449-454, August 2012.

[42]. A. Yildiz, Ş. Horzum, N. Serin and T. Serin "Hopping conduction in In-doped CuO thin films", Applied Surface Science, vol. 318, pp. 105-107, November 2014. 